\title{
The Utility of Dreissena polymorpha for Assessing the Viral Contamination of Rivers by Measuring the Accumulation of F-Specific RNA Bacteriophages
}

\author{
Sandrine Capizzi-Banas ${ }^{1}$, Mélissa Palos Ladeiro ${ }^{2}$, Fanny Bastien ${ }^{2}$, Isabelle Bonnard ${ }^{2}$, Nicolas Boudaud ${ }^{3}$, \\ Christophe Gantzer ${ }^{1}$ and Alain Geffard ${ }^{2, *(\mathbb{D})}$
}

1 Laboratoire de Chimie Physique et Microbiologie pour l'Environnement, UMR 7564, Institut Jean Barriol, Faculté des Sciences et Technologies, Université de Lorraine, LCPME, F-54506 Vandœuvre-lès-Nancy, France; sandrine.capizzi@univ-lorraine.fr (S.C.-B.); christophe.gantzer@univ-lorraine.fr (C.G.)

2 Unité Stress Environnementaux et Biosurveillance des Milieux Aquatiques, UMR-I 02 UFR, Sciences Exactes et Naturelles, Moulin de la Housse, BP 1039, Université Reims Champagne Ardenne, SEBIO, 51687 Reims, France; melissa.palos@univ-reims.fr (M.P.L.); donaz.fanny@hotmail.fr (F.B.); isabelle.bonnard@univ-reims.fr (I.B.)

3 Food Safety Department, Actalia, F-50000 Saint-Lô, France; n.boudaud@actalia.eu

* Correspondence: alain.geffard@univ-reims.fr

Citation: Capizzi-Banas, S.; Palos Ladeiro, M.; Bastien, F.; Bonnard, I.; Boudaud, N.; Gantzer, C.; Geffard, A. The Utility of Dreissena polymorpha for Assessing the Viral Contamination of Rivers by Measuring the Accumulation of F-Specific RNA Bacteriophages. Water 2021, 13, 904.

https://doi.org/10.3390/w13070904

Academic Editor: Françoise S. LUCAS

Received: 10 February 2021

Accepted: 23 March 2021

Published: 26 March 2021

Publisher's Note: MDPI stays neutral with regard to jurisdictional claims in published maps and institutional affiliations.

Copyright: (C) 2021 by the authors Licensee MDPI, Basel, Switzerland. This article is an open access article distributed under the terms and conditions of the Creative Commons Attribution (CC BY) license (https:// creativecommons.org/licenses/by/ $4.0 /)$.
Abstract: River water that receives treated wastewater can be contaminated by pathogens including enteric viruses due to fecal pollution, which may represent an important public health hazard. There is a great diversity of enteric viruses and fecal bacteriophages, especially F-specific RNA bacteriophages (FRNAPHs), are commonly proposed as indicators of viral pollution due to a variety of characteristics such as their structural similarities to the main enteric viruses, their high concentrations in raw wastewater and their environmental survival rate, which is better than other cultivable enteric viruses. However, evaluating the viral contamination of water on the basis of FRNAPH concentration levels continues to present a challenge. This is because the quality of detection is strongly dependent on the quantity of viral particles, high spatio-temporal variabilities and the physico-chemical conditions of the water during sampling. To overcome these limitations, the present study aims to evaluate whether the bivalve mollusk Dreissena polymorpha (zebra mussel) could be considered a suitable experimental model for assessing the viral contamination of rivers. In order to determine this, the capacity of D. polymorpha to accumulate FRNAPHs and assimilate them into their soft tissue was studied. This provided a proof of concept for the use of D. polymorpha to evaluate the viral contamination of surface water. Two experiments were conducted: (1) an in situ experiment to confirm that zebra mussels naturally accumulated FRNAPHs and (2) a laboratory experiment to determine the accumulation and depuration kinetics of FRNAPHs in D. polymorpha tissue. The study highlights the capacity of the mussels to accumulate infectious FRNAPHs both on a laboratory scale under controlled conditions as well as in situ at different sites that are representative of different bodies of water. An analysis of the mussels' soft tissue showed that they were capable of reflecting the water's contamination level very quickly (within less than $24 \mathrm{~h}$ ). Moreover, the soft tissue retained the viral load much longer than the water due to a low depuration rate. The analysis of FRNAPH concentrations in mussels exposed in situ suggested that there were differences in contamination levels between sites. These preliminary results underline the potential utility of zebra mussels in assessing viral contamination by measuring the accumulation of FRNAPHs in their tissue. This may ultimately enable stakeholders to use zebra mussels as a means of monitoring viral pollution in surface water.

Keywords: bacteriophage; surface water; mollusk; bioaccumulation; biomonitoring 


\section{Introduction}

River water is often used as a source of drinking water, to irrigate crops or for recreational purposes. However, it can be contaminated by many pathogens, especially enteric viruses, due to fecal pollution. The enteric viruses most frequently involved in waterborne outbreaks are human noroviruses (HuNoV), adenoviruses, enteroviruses and some hepatitis viruses [1,2]. The small size of these viral particles (ranging between $25-100 \mathrm{~nm}$ ), together with the low infectious dose of enteric viruses ( 10-1000 infectious units) and their high viral load in stools $\left(\sim 10^{6}-10^{9}\right.$ particles/g) and high environmental survival rates make them significant pollutants of river water [3-6]. Assessing the viral contamination of water is challenging because of the rich diversity of enteric viruses, their low concentrations in water and the lack of routine cell culture systems that can be used to evaluate their infectivity. The molecular tools widely used to detect the genomes of these enteric viruses cannot be used to determine their infectivity. In addition, concerning surface water, high volumes of water (1-1000 L) from a single sampling point generally need to be concentrated into small volumes $(0.1-1 \mathrm{~mL})$ for analysis.

Fecal bacteriophages are commonly proposed as indicators of viral pollution $[7,8]$. F-specific RNA bacteriophages (FRNAPHs) belonging to the Leviviridae family are particularly useful because of their structural similarities to the main waterborne enteric viruses [9-11]. Infectious FRNAPHs can also be easily quantified using standardized methods [12]. Molecular tools are also available to quantify the genomes of all four FRNAPH genogroups $[13,14]$, which are commonly found in the environment. Of the four, genogroups II and III are generally associated with human fecal contamination $[10,15]$ while genogroup I is associated with both human and animal fecal pollution. Genogroup IV is associated with animal fecal contamination. FRNAPHs belonging to genogroup III and IV have a low environmental resistance meaning they are limited to use in detecting recent contaminations [10]. FRNAPHs are present in surface water at a fairly wide range of concentrations depending on the level of fecal pollution, i.e., from 0 (the complete absence of phages) to $10^{5} \mathrm{PFU}$ (plaque forming units) $/ 100 \mathrm{~mL}[10,16,17]$. FRNAPHs, especially those belonging to genogroups I and II, are also highly resistant to UV radiation and have a better environmental survival rate than other cultivable enteric viruses especially at temperatures below $25^{\circ} \mathrm{C}$ [8].

No replication is expected in surface waters [8] and their spread depends on hydroclimatic conditions $[16,17]$. Thunderstorms and heavy rainfall have the greatest impact on water quality $[17,18]$. These climatic events may increase viral concentrations in rivers as a result of the overflow of wastewater treatment plants or runoff. Whether and to what extent viral particles are present also depends on their interactions with other particles suspended in water or sediments [17]. In surface waters, FRNAPHs are part of a complex ecodynamic affected by variations in fecal pollution, the differential survival of enteric viruses, interactions with particles and hydroclimatic conditions. Assessing the viral pollution of surface water, which involves monitoring the presence of FRNAPHs, is therefore far from easy.

To overcome all of these issues, an accumulator organism can be used to monitor viral pollution. Bivalves and crustaceans are known to be useful accumulators of contaminants and can be used to continuously monitor and provide long-term insights into surrounding contamination levels $[19,20]$. They are often proposed as tools for monitoring the chemical contamination of water [21-23]. Likewise, the concentrations of FRNAPHs and other enteric viruses in bivalve mollusks are traditionally used to monitor pollution in the context of public health $[24,25]$. The zebra mussel (Dreissena polymorpha) is a continental bivalve mollusk extensively used to monitor inland waters $[23,26,27]$. This bivalve's bioecological traits (i.e., its abundance, wide distribution and filtration activity) make it a useful sentinel species especially as its tolerance of transplantation allows for the active monitoring of various types of water bodies. Moreover, $D$. polymorpha is one of only a few inland water bivalve species with a sessile (rather than intrasedimentary) lifestyle. Bivalves have a high water filtration capacity, which allows them to bioaccumulate many 
different types of contaminants present in the aquatic environment [21,28]. This species' potential utility for assessing protozoa water contamination was recently demonstrated under laboratory conditions and in situ $[27,29,30]$. No data are currently available on the potential presence/accumulation of viral indicators such as FRNAPHs in D. polymorpha. However, a few studies have shown that $D$. polymorpha can accumulate other enteric viruses $[31,32]$.

This study aims to evaluate whether the bivalve mollusk Dreissena polymorpha (zebra mussel) could be considered a suitable experimental model for assessing the viral contamination of rivers. Two experiments were conducted:

1. an in situ experiment to confirm that D. polymorpha naturally accumulates FRNAPHs,

2. a laboratory experiment to determine the accumulation and depuration kinetics of FRNAPHs in D. polymorpha tissue.

\section{Materials and Methods}

\subsection{Mussel Collection and Maintenance}

For both experiments, adult zebra mussels (of 18-22 $\mathrm{mm}$ ) were collected from the Lac

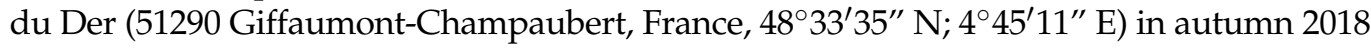
and brought back to the laboratory where they were kept in $40 \mathrm{~L}$ glass tanks of aerated Cristaline Aurele drinking water at $12{ }^{\circ} \mathrm{C}$. The acclimation period lasted three weeks. The mussels were fed with two microalgae species (Scenedesmus obliquus and Chlorella pyrenoidosa, using 1,000,000 microalgae of each species per mussel) twice a week and the water was also changed twice a week. Following the acclimation period, a pool containing five individuals was checked to confirm the absence of phages from their tissue before both the in situ and laboratory experiments.

\subsection{Experimental Design}

\subsubsection{The In Situ Experiment}

Different sites in the French Reference Network (Water Framework Directive, WFD) representative of different bodies of water were selected for the purposes of monitoring the quality of the natural surface water. The sites were chosen in collaboration with the Regional Public Water Agency (https: / /rhin-meuse.eaufrance.fr/ accessed date 10 September 2018) to represent a range of different anthropogenic pressures (resulting from industrial, urban and agricultural activities). Eleven sites in the Grand Est region were selected to represent various types of hydrological systems with a wide range of physico-chemical characteristics. After acclimation, D. polymorpha mussels were randomly distributed into experimental $5 \mathrm{~mm}$ mesh polyethylene cages $(7 \times 7 \times 19 \mathrm{~cm})(200$ mussels per cage $)$ and left at the 11 sites for two months (from mid-October to mid-December 2018) (Figure 1). All of the cages were directly anchored to the bank using wire and ballasted over a distance of $2 \mathrm{~m}$ at a depth of about $40 \mathrm{~cm}-1 \mathrm{~m}$, depending on the site (river size). The conductivity, dissolved oxygen and $\mathrm{pH}$ were measured at the beginning and end of the exposure period using a handheld multiparameter probe $\left(\mathrm{pHenomenal}^{\circledR} \mathrm{MU} 6100 \mathrm{H}\right)$. For each parameter, the average values corresponding to the mean of these two measurements were considered. The dissolved oxygen and $\mathrm{pH}$ values at the different sites were relatively similar ( $\mathrm{pH}$ ranged from 7.7 to 8.4; $\mathrm{O}_{2}$ ranged from 8.4 to $11.2 \mathrm{mg} / \mathrm{L}$ ) except at Petite Rosselle, which had a lower dissolved oxygen concentration $(5.1 \mathrm{mg} / \mathrm{L})$. By contrast, a wide range of conductivity levels was observed. In the Meuse basin, values ranged from $136 \mu \mathrm{S} / \mathrm{cm}$ at Fromelennes (on the Houilles, a tributary of the Meuse) to $642 \mu \mathrm{S} / \mathrm{cm}$ at Saint-Mihiel. At Millery, on the Moselle, the mean conductivity was $1731 \mu \mathrm{S} / \mathrm{cm}$. On the Sarre watershed, the mean conductivity ranged from $330 \mu \mathrm{S} / \mathrm{cm}$ at Sarraltroff to $1882 \mu \mathrm{S} / \mathrm{cm}$ at Petite Rosselle (on the Rosselle, a tributary of the Sarre). At the Ill watershed, the mean conductivity ranged from $470 \mu \mathrm{S} / \mathrm{Cm}$ at Colmar to $1115 \mu \mathrm{S} / \mathrm{cm}$ at Mundolsheim on the Souffel (a tributary of the Ill). The temperature was measured continuously using a probe (Hobo MX2201); the values corresponded to the average of the daily mean temperatures. The temperatures at the different sites were relatively similar, ranging from $8.5^{\circ} \mathrm{C}$ at Fromelennes to $10.6^{\circ} \mathrm{C}$ 
at Millery, except at Petite Rosselle, which had a mean temperature of $12.2^{\circ} \mathrm{C}$. At the end of the exposure period, three pools containing whole soft tissue from five individual mussels were sampled per site and weighed and stored at $-80{ }^{\circ} \mathrm{C}$ prior to the quantification of infectious FRNAPHs (the remaining organisms were used in another study).

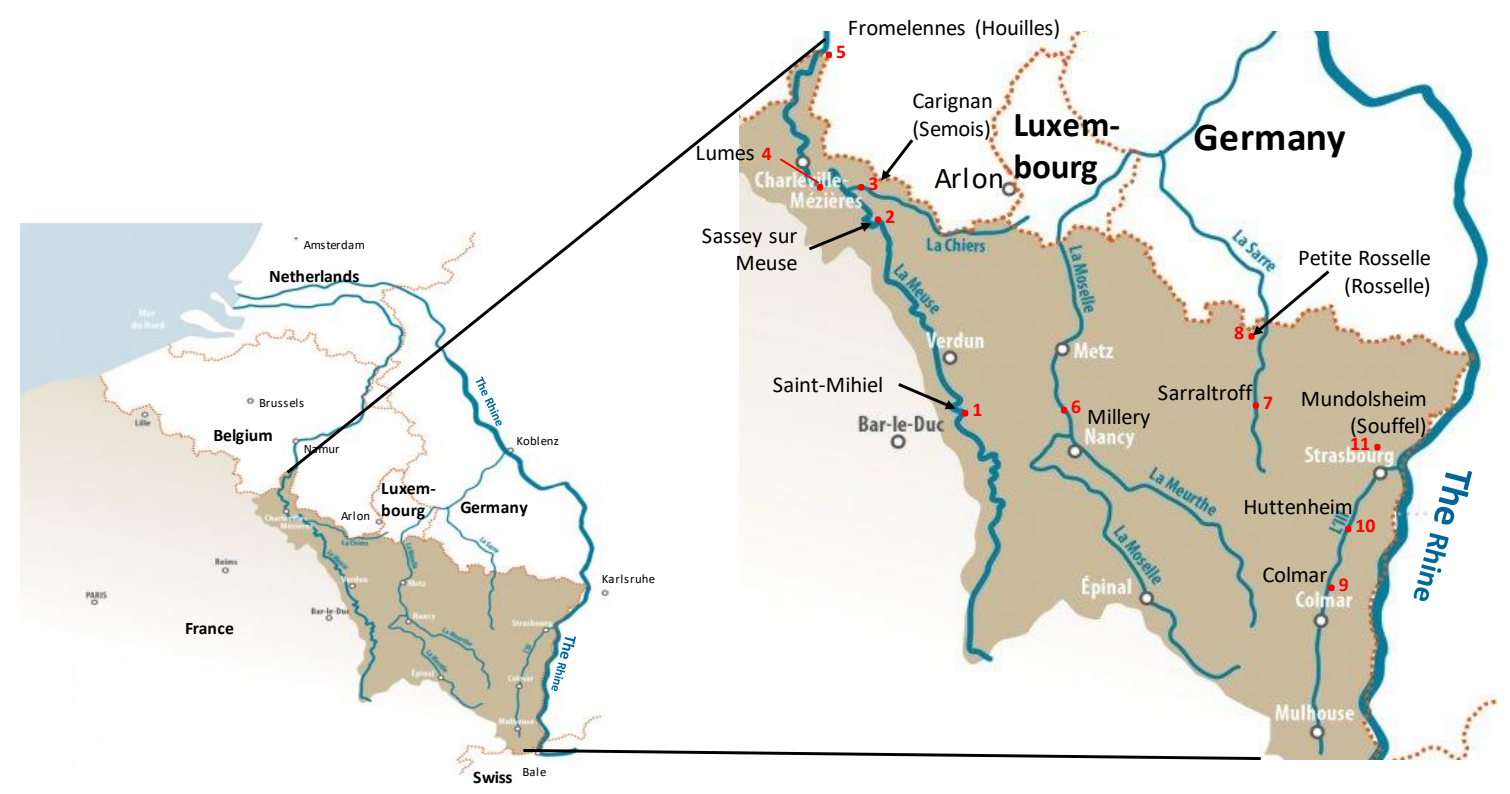

Figure 1. The geographical locations of the eleven experimental sites (1-11). Several sites were located on the tributaries of major rivers (the Meuse, Moselle, Sarre and Ill). The tributaries are indicated in brackets.

\subsubsection{Laboratory Experiments}

On the day prior to the laboratory scale experiment, 50 mussels were placed in two $6 \mathrm{~L}$ tanks of Cristaline Aurele drinking water (similar to maintenance conditions) and kept at $12{ }^{\circ} \mathrm{C}$. The experiment was conducted over a period of three weeks with two pulses of FRNAPHs, one on day 0 and one on day 7 , a final concentration in each tank of $10^{3}(1 \mathrm{X})$ or $10^{5}(100 \mathrm{X}) \mathrm{PFU} / \mathrm{mL}$; and a depuration step in FRNAPH-free water from days 14-21. The infectious FRNAPH suspension was composed of a mixture of phages belonging to genogroups I (GGI) and II (GGII) (MS2, F-Specific RNA Bacteriophage belonging to the Subgroup I and GA, F-Specific RNA Bacteriophage belonging to the Subgroup II, phages, respectively) because they have a better environmental survival rate in water than the other two genogroups, III and IV [10]. A ratio of 30\% MS2 phages to $70 \%$ GA phages was used to mimic the ratio of genogroups I and II in raw urban wastewater [10]. Stock phage suspensions were produced in accordance with the ISO procedure (ISO 107051, 2001 [33]). The concentrations were between $10^{8}$ and $10^{10} \mathrm{PFU} / \mathrm{mL}$ as determined by the quantification procedure described in Section 2.3. The mussels were fed twice a week as in the maintenance conditions (see 2.1) and the water was changed on day 7 prior to the second pulse and on day 14 prior to the depuration step. The tanks were also replaced on day 14 prior to the depuration step. A total of $5 \mathrm{~mL}$ of water was sampled prior to the quantification of infectious FRNAPHs and stored at $-80^{\circ} \mathrm{C}$ until the analysis. During the exposure step, the water was sampled on days 1,3 and 7 (just before the water was changed and the second pulse); day 8 (24 h after the second pulse) and days 10, 12 and 14. During the depuration step, the water was sampled on days 15 ( $24 \mathrm{~h}$ after changing the water and tanks), 17, 19 and 21. Likewise, a representative pool containing whole soft tissue from five mussels for each condition was sampled on days 1, 2, 7, 14 and 21 and weighed and stored at $-80^{\circ} \mathrm{C}$ prior to the quantification of the infectious FRNAPHs. 


\subsection{Quantification of Infectious FRNAPHs}

The FRNAPHs in the water and mussel samples were counted. The frozen samples of around $1.5 \mathrm{~g}$ of whole soft mussel tissue (from at least five individuals) were mixed with two volumes of a solution of PBS (Phosphate Buffered Saline, $150 \mathrm{mM}$ ) and $0.3 \%$ peptone in a DT-20 tube with an ULTRA-TURRAX ${ }^{\circledR}$ Tube Drive (IKA-Werke GmbH and Co. KG, Staufen, Germany) for $3 \mathrm{~min}$. Following centrifugation ( $2000 \times g$ for $5 \mathrm{~min})$, the supernatant was collected and used for the enumeration. The enumeration was performed directly on $1 \mathrm{~mL}$ samples of several different dilutions of the supernatants from the mussel tissue samples and $1 \mathrm{~mL}$ of water (from the $5 \mathrm{~mL}$ sampled in the tanks) in petri dishes of $90 \mathrm{~mm}$ in diameter following the standard procedure (ISO 10705-1, 2001 [33]). FRNAPHs were quantified using Salmonella enterica serovar Typhimurium WG49 (National Collection of Type Culture 12484) as the host strain [34]. Kanamycin and nalidixic acid were added to obtain a final antibiotic concentration of $100 \mu \mathrm{g} / \mathrm{mL}$ during titration. Each titration was realized in triplicate. Viral concentrations and standard deviations were expressed in PFU per milliliter or gram of soft tissue (fresh weight, fw).

\subsection{Statistical Treatment}

Assumptions of normality (using the Shapiro-Wilk normality test) and the homogeneity of variance (using Levene's test) were verified before analyzing data from the in situ experiments. As normality was not confirmed, a non-parametric analysis of variance was performed using the Kruskall-Wallis test followed by a post-hoc Dunn's multiple pairwise comparison test with a Bonferroni factor using XLSTAT (2017, addinsoft, Paris France).

The time required to obtain a 90\% reduction (T90) in the concentration of the FRNAPHs in the water and in the mussels was calculated using trend curve equations obtained from the experimental data. The T90s of the two viral concentrations (1X and 100X) during days 0-7 and days 8-21, respectively, were determined. The mean T90 in water and mollusk tissue were compared using the Kolmogorov and Smirnov test (XLSTAT, 2017)

\section{Results and Discussion}

The first part of this study focused on the accumulation of FRNAPHs in D. polymorpha mussels under natural conditions at representative surface water body sites within the WFD. Zebra mussels were left at several locations subject to different anthropic impacts for two months. The concentrations of total infectious FRNAPHs are shown in Figure 2. No infectious FRNAPHs were detected in the control after the mussels' acclimation, immediately before their transplantation or in the mussels exposed at Saint-Mihiel, Sassey or Huttenheim. This result suggests that these three sites were less impacted by anthropic activities. Conversely, the mussels exposed at the other sites accumulated infectious FRNAPHs at a wide range of concentrations. The lowest concentration was measured at Carignan (with a mean of $28 \mathrm{PFU} / \mathrm{g}$ of $\mathrm{fw}$ ), a tributary of the Meuse. The highest concentration was measured at Colmar, on the Ill river (a mean of $1006 \mathrm{PFU} / \mathrm{g}$ of fw), suggesting that the Colmar site, located just downstream of the city, was particularly impacted by anthropic activities. These results were consistent with previous studies showing the accumulation of enteric viruses in D. polymorpha [31,32] as well as the accumulation of infectious FRNAPHs in edible mollusk species $[8,25]$. These results demonstrated for the first time the capacity of zebra mussels to accumulate FRNAPHs under in situ conditions. Our results suggested that the use of $D$. polymorpha could highlight significant $(p<0.005)$ differences in contamination levels between sites. This approach could provide a simple and effective tool that water stakeholders could deploy to improve water quality management. The use of $D$. polymorpha could improve the assessment of the viral contamination of water bodies by increasing the sensitivity of the monitoring system and allowing the comparison of contamination levels by exposing similar organisms for the same length of time at different sites. The infectious FRNAPH content measured at the different sites indicated pollution stemming from various human and/or animal sources. 


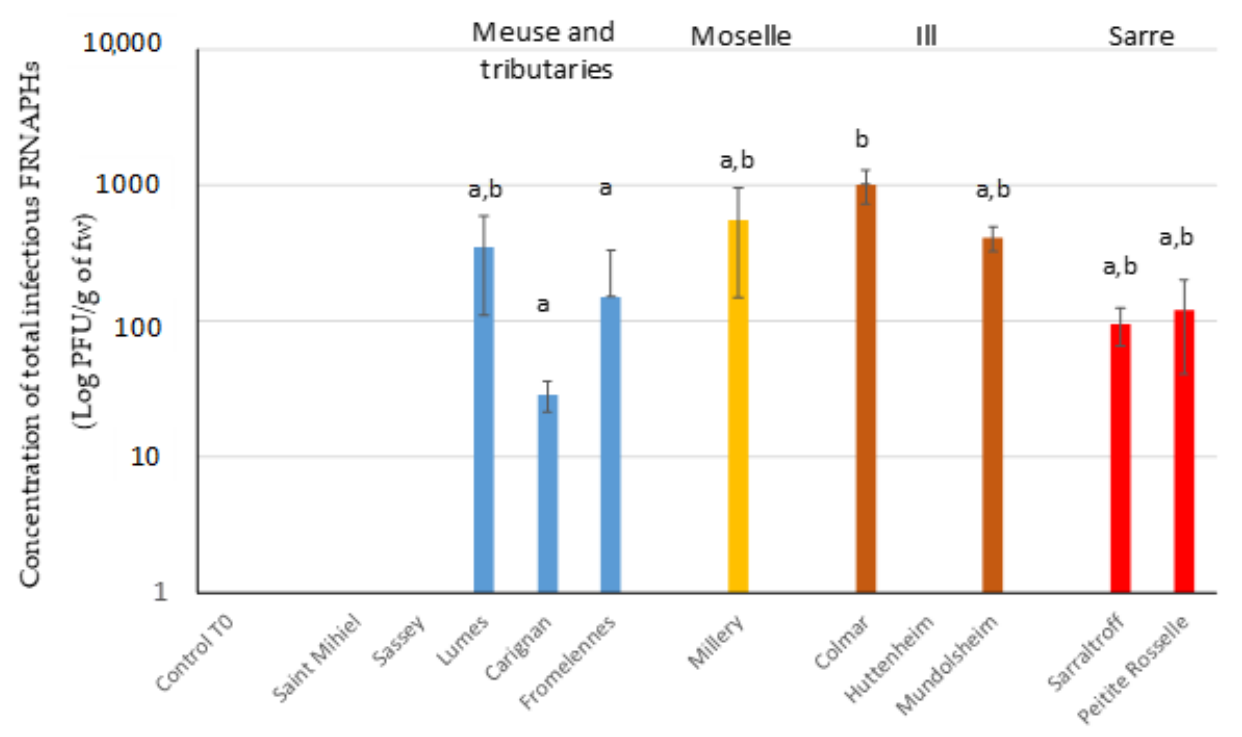

Figure 2. Concentrations of total infectious F-specific RNA bacteriophages (FNRAPHs) (mean \pm SD, $\mathrm{N}=3$; PFU/g fw) quantified in the fresh weight (fw) of zebra mussel soft tissue before (control, T0) and after their introduction at the different sites for two months. Histograms marked with the same letter $(a, b)$ are not statistically different at the $95 \%$ significance level.

The second part of this study focused on FRNAPH accumulation and release kinetics in zebra mussels. The concentrations of infectious FRNAPHs in water and mussel soft tissue were measured continuously throughout the three weeks of the laboratory experiment (Figure 3). Twenty-four hours after the first pulse, the FRNAPH concentrations measured in the water were $2.83 \log _{10} \mathrm{PFU} / \mathrm{mL}$ and $5.39 \log _{10} \mathrm{PFU} / \mathrm{mL}$ under the $1 \mathrm{X}$ and 100X conditions, respectively. At the same point in time, the FRNAPH concentrations measured in the mussels were $3.08 \log _{10} \mathrm{PFU} / \mathrm{g}$ and $5.78 \mathrm{Log}_{10} \mathrm{PFU} / \mathrm{g}$ under the $1 \mathrm{X}$ and $100 \mathrm{X}$ conditions, respectively. The FRNAPH content of the mussels was twice as high as that of the water after one day of exposure. A similar result was obtained after the second pulse (day 8).

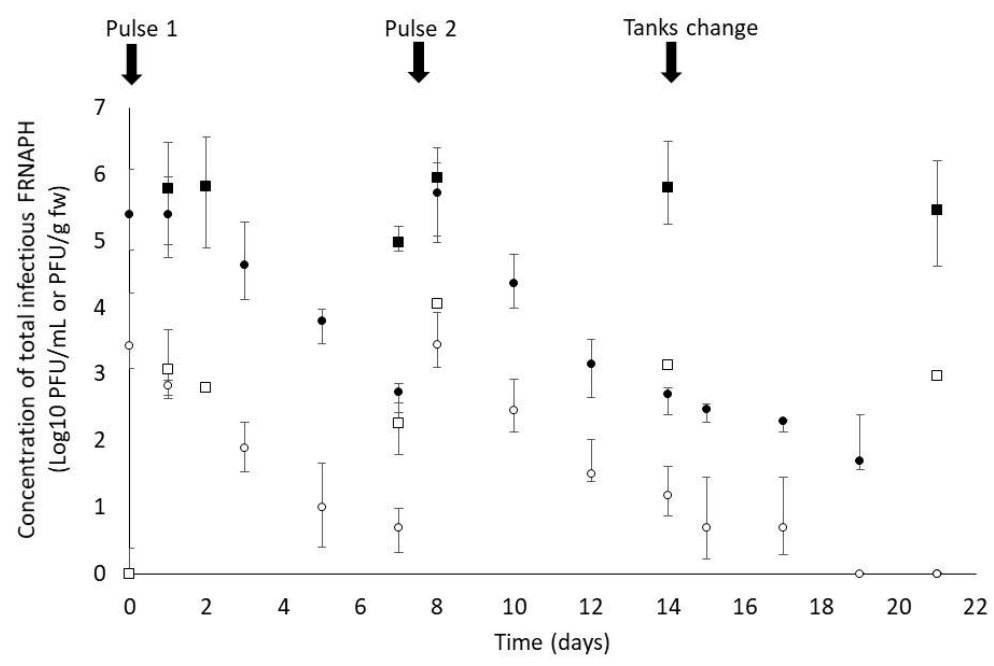

Figure 3. Concentrations of infectious FRNAPHs in water and mussel soft tissue during the contamination and depuration periods. Results are expressed in $\log _{10} \mathrm{PFU} / \mathrm{mL}$ for the FRNAPH content of the water and PFU/g of fresh weight for the FRNAPH content of the mussels. Squares: FRNAPHs in the mussels; circles: FRNAPHs in the water; black: high-density suspension (100X); white: low-density suspension (1X). D0 and D7: inoculation of FRNAPHs containing a ratio of 30\% of GGI (subgroup I) in the form of MS2 phages and 70\% of GGII (subgroup II) in the form of GA phages. The water was changed in all tanks on day 7. 
The FRNAPH decay was substantially slower in the mussels than in the water. In water, the T90 values were 3.39 and 3.43 days at $12{ }^{\circ} \mathrm{C}$ on days $1-7$ for the $1 \mathrm{X}$ and 100X concentrations, respectively. Likewise, the T90 values were 3.02 and 2.67 days at $12{ }^{\circ} \mathrm{C}$ on days $8-21$ for the $1 \mathrm{X}$ and $100 \mathrm{X}$ concentrations, respectively. The average value was 3.13 days for all mixed conditions (concentrations and duration). These T90 values were much lower than those cited in the literature data. Schaper et al. [35] reported no reduction in GGI and GGII FRNAPHs after seven days of exposure in PBS at $4{ }^{\circ} \mathrm{C}$ and $20^{\circ} \mathrm{C}$. However, the authors describe a $1.9 \mathrm{Log}$ reduction in GGII FRNAPHs after seven days of exposure in mineral water or seawater at $20^{\circ} \mathrm{C}$. The faster reduction of infectious FRNAPHs in water observed in this study could be explained in part by the mussels' accumulation capacity (discussed below) but also by other FRNAPH interactions with microalgae used to feed the mussels or with the tank wall.

The mussels' T90 values were 8.12 and 8.31 days at $12{ }^{\circ} \mathrm{C}$ on days $1-7$ for the $1 \mathrm{X}$ and 100X concentrations, respectively. These values were 10.2 and 16.7 days at $12{ }^{\circ} \mathrm{C}$ on days 8-21 for the $1 \mathrm{X}$ and 100X concentrations, respectively. T90 values ranged from 8.12 to 16.7 days and were higher following the second contamination. This highlighted the fact that FRNAPHs were able to survive significantly ( $p=0.037)$ longer in the mussel tissue than in the water with average T90 values of 10.8 days for mussels and 3.13 days in water. Infectious FRNAPHs appeared to be inactivated faster in water than in the mussels, which highlighted the protective effect of the mussel tissue. T90 values of $\sim 20$ days are currently described in the literature for the reduction of infectious FRNAPHs in oysters at $\sim 10^{\circ} \mathrm{C}[25,36]$, which is in the same range as our study.

The final step of our laboratory experiment was to study the depuration of FRNAPHs in D. polymorpha mussels. During the third week of exposure (days 14-21), low and decreasing concentrations of infectious FRNAPHs were observed in the water after the tank and the water had been changed. These infectious FRNAPHs were released by the mussels and could be detected in the water for a few days. The concentrations fell to zero after days 17 and 19 under the $1 \mathrm{X}$ and 100X conditions, respectively. On day 21, the concentrations of $2.99 \log _{10} \mathrm{PFU} / \mathrm{g}$ and $5.46 \mathrm{Log}_{10} \mathrm{PFU} / \mathrm{g}$ were measured in the mussels from the 1X and 100X conditions, respectively. In the mussels, the decrease was very slight; a loss of less than $1 \log _{10} \mathrm{PFU} / \mathrm{g}$ per seven days. These results suggested that specific and/or non-specific interactions between the FRNAPHs and the mussel soft tissue led to low rates of depuration in D. polymorpha. As Leduc et al. [36] suggested, the main mechanism involved in the depuration carried out by the mussels is not the release of FRNAPHs into the water but their inactivation in soft tissue. In this context, it is relevant to understand why and how sentinel species such as zebra mussels process high levels of viral particles in surface water. The assumption that they can process high viral concentrations is supported by data, especially data from studies on the interactions between HuNoVs and the digestive tissue of bivalve mollusks such as mussels (Mytilus edulis) and oysters (Crassostrea gigas) [37,38]. Specific interactions between HuNoVs and some carbohydrates (histo-blood group antigen (HGBA)-like carbohydrates) as well as the sialic acid residues present in bivalve mollusks have been extensively described over the last decade [37-39]. These specific interactions favor $\mathrm{HuNoV}$ accumulation in digestive tissues $[38,40]$. The accumulation of FRNAPHs in the digestive tissue of oysters is also well documented $[25,36,41]$. Further experiments are required to better understand the specific and/or non-specific interactions between infectious FRNAPHs and the soft tissue of zebra mussels. This will improve our knowledge of organotrophic mechanisms.

\section{Conclusions}

Our original results concerning inland waters confirmed the capacity of zebra mussels to accumulate infectious FRNAPHs both on a laboratory scale under controlled conditions and in the field at various sites that were representative of different water bodies. This study highlighted (1) the capacity of zebra mussels to accumulate contaminants and reflect the water's contamination level very quickly (within less than $24 \mathrm{~h}$ ) and (2) their 
capacity to retain the viral load in their soft tissue much longer than in the water due to a lower depuration rate. These results highlighted the fact that zebra mussels are of potential interest to water stakeholders as a practical means of actively monitoring viral surface water pollution. However, further studies are necessary to better characterize the interactions between infectious FRNAPHs and zebra mussels in water. This will improve our knowledge of accumulation and depuration processes. The possible influence of environmental parameters (temperature, trophic level) on the capacity of mussels to accumulate FRNAPHs will have to be addressed with a view to describing the fate of viruses in organisms using modelling tools. The final outcome will enable a more precise assessment of the viral contamination of water bodies through more accurate measurements in mussels.

Author Contributions: Conceptualization, S.C.-B., M.P.L. and A.G.; Methodology, S.C.-B., M.P.L., N.B., C.G. and A.G.; Validation, S.C.-B., M.P.L., N.B., C.G. and A.G.; Formal Analysis, S.C.-B., M.P.L., F.B., I.B. and A.G.; Investigation, S.C.-B., M.P.L., F.B., I.B. and A.G.; Resources, S.C.-B., M.P.L., C.G. and A.G.; Data Curation, S.C.-B., M.P.L., N.B., C.G. and A.G.; Writing-Original Draft Preparation, S.C.-B., M.P.L., N.B., C.G. and A.G.; Writing-Review and Editing, S.C.-B., M.P.L., F.B., I.B., N.B., C.G. and A.G.; Visualization, S.C.-B., M.P.L., N.B., C.G. and A.G.; Supervision, S.C.-B., M.P.L., N.B., C.G. and A.G.; Project Administration, S.C.-B., M.P.L., C.G. and A.G.; Funding Acquisition, S.C.-B., M.P.L., C.G. and A.G. All authors have read and agreed to the published version of the manuscript.

Funding: "This research received no external funding".

Institutional Review Board Statement: "Not applicable" Currently experiments with this biological model are not subject to authorization by an ethical committee.

Informed Consent Statement: "Not applicable".

Data Availability Statement: Data is contained within the article.

Acknowledgments: The results of this study were obtained within the scope of EQUAL, a project funded by the Agence de l'Eau Rhin-Meuse and with the support of CENOPAC (project ISM). This study was also supported by the ACTIA VIROcontrol Joint Technological Unit. The authors are grateful to Matthew Eden for their English language copyediting services.

Conflicts of Interest: The authors declare no conflict of interest.

\section{References}

1. Bosch, A. Human Viruses in Water, 1st ed.; Elsevier: Amsterdam, The Netherlands, 2007; Volume 17.

2. Fout, G.S.; Borchardt, M.A.; Kieke, B.A.; Karim, M.R. Human virus and microbial indicator occurrence in public-supply groundwater systems: Meta-analysis of 12 international studies. Hydrogeol. J. 2017, 25, 903-919. [CrossRef]

3. Atmar, R.L.; Opekun, A.R.; Gilger, M.A.; Estes, M.K.; Crawford, S.E.; Neill, F.H.; Graham, D.Y. Norwalk virus shedding after experimental human infection. Emerg. Infect. Dis. 2008, 14, 1553-1557. [CrossRef] [PubMed]

4. Teunis, P.F.M.; Moe, C.L.; Liu, P.; Miller, S.E.; Lindesmith, L.; Baric, R.S.; Le Pendu, J.; Calderon, R.L. Norwalk virus: How infectious is it? J. Med. Virol. 2008, 80, 1468-1476. [CrossRef] [PubMed]

5. Atmar, R.L.; Opekun, A.R.; Gilger, M.A.; Estes, M.K.; Crawford, S.E.; Neill, F.H.; Ramani, S.; Hill, H.; Ferreira, J. Determination of the 50\% human infectious dose for Norwalk virus. J. Infect. Dis. 2014, 209, 1016-1022. [CrossRef]

6. Kauppinen, A.; Miettinen, I.T. Persistence of Norovirus GII Genome in Drinking Water and Wastewater at Different Temperatures. Pathogens 2017, 6, 48. [CrossRef]

7. Skraber, S.; Gassilloud, B.; Gantzer, C. Comparison of coliforms and coliphages as tools for assessment of viral contamination in river water. Appl. Environ. Microbiol. 2004, 70, 3644-3649. [CrossRef] [PubMed]

8. Jofre, J.; Lucena, F.; Blanch, A.R.; Muniesa, M. Coliphages as Model Organisms in the Characterization and Management of Water Resources. Water 2016, 8, 199. [CrossRef]

9. Lucena, F.; Méndez, X.; Morón, A.; Calderón, E.; Campos, C.; Guerrero, A.; Cárdenas, M.; Gantzer, C.; Shwartzbrood, L.; Skraber, S.; et al. Occurrence and densities of bacteriophages proposed as indicators and bacterial indicators in river waters from Europe and South America. J. Appl. Microbiol. 2003, 94, 808-815. [CrossRef]

10. Hartard, C.; Rivet, R.; Banas, S.; Gantzer, C. Occurrence of and Sequence Variation among F-Specific RNA Bacteriophage Subgroups in Feces and Wastewater of Urban and Animal Origins. Appl. Environ. Microbiol. 2015, 8, 6505-6515. [CrossRef]

11. Flannery, J.; Keaveney, S.; Doré, W. Use of FRNA Bacteriophages to Indicate the Risk of Norovirus Contamination in Irish Oysters. J. Food Prot. 2009, 72, 2358-2362. [CrossRef]

12. Hartard, C.; Banas, S.; Rivet, R.; Boudaud, N.; Gantzer, C. Rapid and sensitive method to assess human viral pollution in shellfish using infectious F-specific RNA bacteriophages: Application to marketed products. Food Microbio. 2017, 63, 48-254. [CrossRef] 
13. Ogorzaly, L.; Gantzer, C. Development of real-time RT-PCR methods for specific detection of F-specific RNA bacteriophage genogroups: Application to urban raw wastewater. J. Virol Methods 2006, 138, 131-139. [CrossRef] [PubMed]

14. Wolf, S.; Hewitt, J.; Greening, G.E. Viral multiplex quantitative PCR assays for tracking sources of fecal contamination. Appl. Environ. Microbiol. 2010, 76, 1388-1394. [CrossRef] [PubMed]

15. Cole, D.; Long, S.C.; Sobsey, M.D. Evaluation of F+ RNA and DNA Coliphages as Source-Specific Indicators of Fecal Contamination in Surface Waters. Appl. Environ. Microbiol. 2003, 69, 6507-6514. [CrossRef]

16. Fauvel, B.; Cauchie, H.-M.; Gantzer, C.; Ogorzaly, L. Contribution of hydrological data to the understanding of the spatio-temporal dynamics of F-specific RNA bacteriophages in river water during rainfull-runoff events. Water Res. 2016, 94, 328-340. [CrossRef] [PubMed]

17. Fauvel, B.; Ogorzaly, L.; Cauchie, H.M.; Gantzer, C. Interactions of infectious F-specific RNA bacteriophages with suspended matter and sediment: Towards an understanding of FRNAPH distribution in a river water system. Sci. Total Environ. 2017, 574, 960-968. [CrossRef]

18. Carlton, E.J.; Eisenberg, J.N.S.; Goldstick, J.; Cevallos, W.; Trostle, J.; Levy, K. Heavy rainfall events and diarrhea incidence: The role of social and environmental factors. Am. J. Epidemiol. 2014, 179, 344-352. [CrossRef] [PubMed]

19. Stumpf, P.; Failing, K.; Papp, T.; Nazir, J.; Böhm, R.; Marschang, R.E. Accumulation of a low pathogenic avian influenza virus in zebra mussels (Dreissena polymorpha). Avian Dis. 2010, 54, 1183-1190. [CrossRef] [PubMed]

20. La Rosa, G.; Mancini, P.; Bonanno Ferraro, G.; Iaconelli, M.; Veneri, C.; Paradiso, R.; De Medici, J.D.; Vicenza, T.; Proroga, Y.T.R.; Di Maro, O.; et al. Hepatitis A Virus Strains Circulating in the Campania Region (2015-2018) Assessed through Bivalve Biomonitoring and Environmental Surveillance. Viruses 2020, 13, 16. [CrossRef]

21. Bourgeault, A.; Gourlay-Francé, C.; Vincent-Hubert, F.; Palais, F.; Geffard, A.; Biagianti-Risbourg, S.; Pain-Devin, S.; TusseauVuillemin, M.-H. Lessons from a transplantation of zebra mussels into a small urban river: An integrated ecotoxicological assessment. Environ. Toxicol. 2010, 25, 468-478. [CrossRef]

22. Besse, J.P.; Coquery, M.; Lopes, C.; Chaumot, A.; Budzinski, H.; Labadie, P.; Geffard, O. Caged Gammarus fossarum (Crustacea) as a robust tool for the characterization of bioavailable contamination levels in continental waters: Towards the determination of threshold values. Water Res. 2013, 47, 650-660. [CrossRef] [PubMed]

23. Palos Ladeiro, M.; Barjhoux, I.; Bigot-Clivot, A.; Bonnard, M.; David, E.; Dedourge-Geffard, O.; Geba, E.; Lance, E.; Lepretre, M.; Magniez, G.; et al. Mussel as a tool to define continental watershed quality. Org. Mol. Malacol. 2007. [CrossRef]

24. Muniain-Mujika, I.; Calvo, M.; Lucena, F.; Girones, R. Comparative analysis of viral pathogens and potential indicators in shellfish. Int. J. Food Microbiol. 2003, 83, 75-85. [CrossRef]

25. Hartard, C.; Leclerc, M.; Rivet, R.; Maul, A.; Loutreul, J.; Banas, S.; Boudaud, N.; Gantzer, C. F-specific RNA bacteriophages, especially members of subgroup II, should be reconsidered as good indicators of viral pollution of oysters. Appl. Environ. Microbiol. 2018, 84, e01866-17. [CrossRef] [PubMed]

26. Binelli, A.; Della Torre, C.; Magni, S.; Parolini, M. Does zebra mussel (Dreissena polymorpha) represent the freshwater counterpart of Mytilus in ecotoxicological studies? A critical review. Environ. Pollut. 2015, 196, 386-403. [CrossRef] [PubMed]

27. Kerambrun, E.; Palos Ladeiro, M.; Bigot-Clivot, A.; Dedourge-Geffard, O.; Dupuis, E.; Villena, I.; Aubert, D.; Geffard, A. Zebra mussel as a new tool to show evidence of freshwater contamination by waterborne Toxoplasma gondii. J. Appl. Microbiol. 2016, 120, 498-508. [CrossRef] [PubMed]

28. Bervoets, L.; Voets, J.; Covaci, A.; Chu, S.; Qadah, D.; Smolders, R.; Schepens, P.; Blust, R. Use of transplanted zebra mussels (Dreissena polymorpha) to assess the bioavailability of microcontaminants in flemish surface waters. Environ. Sci. Technol. 2005, 39, 1492-1505. [CrossRef]

29. Palos Ladeiro, M.; Aubert, D.; Villena, I.; Geffard, A.; Bigot, A. Bioaccumulation of human waterborne protozoa by zebra mussel (Dreissena polymorpha): Interest for water biomonitoring. Water Res. 2014, 48, 148-155. [CrossRef]

30. Géba, E.; Aubert, D.; Durand, L.; Escotte, S.; La Carbona, S.; Cazeaux, C.; Bonnard, I.; Bastien, F.; Palos Ladeiro, M.; Dubey, J.P.; et al. Use of the bivalve Dreissena polymorpha as a biomonitoring tool to reflect the protozoan load in freshwater bodies. Water Res. 2020, 170, 115297. [CrossRef]

31. Mezzanotte, V.; Marazzi, F.; Bissa, M.; Pacchioni, S.; Binelli, A.; Parolini, M.; Magni, S.; Franco, M.; Ruggeri, F.; De Giuli Morghen, C.; et al. Removal of enteric viruses and Escherichia coli from municipal treated effluent by zebra mussels. Sci. Total Environ. 2016, 539, 395-400. [CrossRef]

32. Bighiu, M.A.; Haldén, A.N.; Goedkoop, W.; Ottoson, J. Assessing microbial contamination and antibiotic resistant bacteria using zebra mussels (Dreissena polymorpha). Sci. Total Environ. 2019, 650, 2141-2149. [CrossRef]

33. International Organization for Standardization. Water Quality—Detection and Enumeration of Bacteriophages—Part 1: Enumeration of F-Specific RNA Bacteriophages; ISO 10705-1; International Organization for Standardization: Geneva, Switzerland, 2001.

34. Havelaar, A.H.; Hogeboom, W.M. A method for the enumeration of male-specific bacteriophages in sewage. J. Appl. Bacteriol. 1984, 56, 439-447. [CrossRef]

35. Schaper, M.; Jofre, J.; Uys, M.; Grabow, W.O.K. Distribution of genotypes of F-specific RNA bacteriophages in human and non-human sources of faecal pollution in South Africa and Spain. J. Appl. Microbiol. 2002, 92, 657-667. [CrossRef] [PubMed]

36. Leduc, A.; Leclerc, M.; Challant, J.; Loutreul, J.; Robin, M.; Maul, A.; Majou, D.; Boudaud, N.; Gantzer, C. F-Specific RNA bacteriophages model the behavior of human noroviruses during purification of oysters: The main mechanism is probably inactivation rather than release. Appl. Environ. Microbiol. 2020, 86, e00526-20. [CrossRef] [PubMed] 
37. Le Guyader, F.; Loisy, F.; Atmar, R.L.; Hutson, A.M.; Estes, M.K.; Ruvoën-Clouet, N.; Pommepuy, M.; Le Pendu, J. Norwalk virus-specific binding to oyster digestive tissues. Emerg. Infect. Dis. 2006, 12, 931-936. [CrossRef] [PubMed]

38. Tian, P.; Engelbrektson, A.L.; Jiang, X.; Zhong, W.; Mandrell, R.E. Norovirus recognizes histo-blood group antigens on gastrointestinal cells of clams, mussels, and oysters: A possible mechanism of bioaccumulation. J. Food Protect. 2007, 70, $2140-2147$. [CrossRef]

39. Maalouf, H.; Schaeffer, J.; Parnaudeau, S.; Le Pendu, J.; Atmar, R.L.; Crawford, S.E.; Le Guyader, F.S. Strain-dependent norovirus bioaccumulation in oysters. Appl. Environ. Microbiol. 2011, 77, 3189-3196. [CrossRef]

40. Maalouf, H.; Zakhour, M.; Pendu, J.L.; Le Saux, J.-C.; Atmar, R.L.; Le Guyader, F.S. Distribution in tissue and seasonal variation of norovirus genogroup I and II ligands in oysters. App. Environ. Microbiol. 2010, 76, 5621-5630. [CrossRef]

41. Lowther, J.A.; Cross, L.; Stapleton, T.; Gustar, N.E.; Walker, D.I.; Sills, M.; Treagus, S.; Pollington, V.; Lees, D.N. Use of F-Specific RNA Bacteriophage to Estimate Infectious Norovirus Levels in Oysters. Food. Environ. Virol. 2019, 11, 247-258. [CrossRef] 